\title{
WORLD TRADE AFTER COVID-19 PANDEMIC SHOCK - RECOVERY OR STAGNATION?
}

\author{
Marzina Akhter \\ Student of MA in Global Trade Management \\ Worms University of Applied Sciences, Germany \\ MBA \& BBA in Accounting \& Information Systems, Comilla University, Bangladesh \\ E-mail: morzina.cou1@gmail.com
}

Received: August 08, 2021 Accepted: August 29, 2021 Online Published: September 26, 2021

DOI: 10.46545/aijbms.v3i1.205

URL: https://doi.org/10.46545/ aijbms.v3i1.205

\begin{abstract}
Globalization has shorten the world \& make the life easier. It also results liberalization of trade. Hence, world trade or global trade acts as a coordinator of foreign trade of different countries. Due to the behavioral and structural position, world trade is also responsible for spreading crises and infectious diseases. Nowadays the world is facing a perilous situation for worldwide spreading of COVID-19 pandemic. The acceleration of this pandemic causes the deceleration of the normal life of the nations. The leaders of most of the countries implement restrictive policies to protect their citizens from this pandemic, i.e., lockdown, travel restrictions. Consequently, COVID-19 produces an economic impact through the interruptions of personal income, world trade, and demand \& supply chain. After the last financial crisis 2008-09, the world is again facing a destructive fall in world trade. The aim of this paper is to provide an overview of world trade during COVID-19 and the present situation of this whether it is in stagnation or recovery. The paper uses secondary data from different journals, websites, newspapers and blogs for analysis purposes. This paper concludes that the world merchandise trade's recovery is stronger than the world services trade. The reasons for sluggish world services trade is the restricted international travels \& tourisms. There is no equal merchandise trade recovery for all the countries. Some countries are winners \& some are losers.
\end{abstract}

Keywords: World trade, COVID-19, financial crisis, Globalization.

JEL Classification Codes: F10, F60, G01.

\section{INTRODUCTION}

World trade gives a platform to the countries to exchange their goods and services. The countries can avail themselves of getting products or services which are costly or not available to them domestically. When a person can buy five different products originally produced by five different countries from a super shop, he is taking advantage of world trade. So, trade acts as a hub of making connections between countries (Koka, Prescott, \& Madhavan, 1999). Trade is an important part of growth \& a fundamental portion of human social organization. After the Second World 
War, the management process of social, political and economic factors recognized globalization which includes controlling of capital flow and liberalization of trade (Khan, 2020; Serrano \& Boguñá, 2003). Consequently, this liberalization strategy has made the world smaller like a village. The most recent COVID-19 has emerged from China in December 2019 and spreads as a pandemic to all over the world. As of May 1, more than 153 million people confirmed the covid-19 cases and 3.2 million people have died due to this cause. This pandemic has caused a long-term imbalance across income groups \& discontinued availability of essential medicine and health services (World Health Statistics, 2021). It is not only a health disease but also affects the world economically, politically, socially, psychologically, and educationally. This causes a deglobalization with a shock in educational, tourism, investment and export \& import sectors (HASSANI \& DOST, 2020). Foe instances, most of the countries in the world have physically closed their educational institutions to reduce the spreading of this pandemic (Salik \& Chowdhury, 2020). In the business organization rewards and recognition policies are important for employee engagement (Baqir, Hussain, Waseem, \& Islam, 2020). Due to this pandemic period companies fail to manage this. Most of the cases they choose retrenching of the employees. There is an unusual economic ramifications and employees are losing their jobs (Imran \& Ahmed, 2020). World trade is also hampered by this pandemic. Globalized world trade (moving plants, animals and other materials) is also responsible for spreading infectious disease (Relman, Choffnes, \& Mack, 2010). Due to this structure of the world trade system, it is not only a channel of exchanging goods and services but also can be a channel of spreading crises (Glick \& Rose, 1999). For instance, the impact of this pandemic on trade has not just confined to one or two countries rather it spreads all over the world. As the third wave of COVID-19 has started, this pandemic situation is continuing for a long time. The world is searching for solutions to retrieve from this. So, what is the recent development in world trade after this pandemic shock? Is it recovering or in a stagnation situation? The aim of this study is to find out the answers of these questions. The analysis of this study is based on the secondary data. The data are collected from journals, published research articles, websites, blogs etc.

\section{OVERVIEW OF WORLD TRADE}

As the concept of David Ricardo, global trade or world trade can be recognized as a comparative advantage. A country can be in a comparative advantage position by making a specific goods or giving services at a lower cost than other countries (Ruffin, 2002). For instance, the garment industry of Bangladesh is in a comparative advantage position due to its lower labor costs. Hence, World trade collaborates the specialization of different countries and makes an exchanging platform among these countries. The World Trade Organization (WTO) acts as a media of setting rules and regulations for world trade. Its aim is to help the nations doing their trade in a flexible, free and easier way. Since 29th July 2016, it has 164 members and most of the trades have taken place under the rules and regulations of world trade. According to the former Director-General Roberto Azevêdo of the WTO, in 2016, 98 percent of world merchandise trade occurred under WTO rules. World trade can play a vital role to accelerate national development, economic growth and job creation. In 2017, world merchandise recorded its highest growth in the last six years, the ratio of trade growth to GDP growth returned to 1.5 , above the 1.0 ratio recorded in the years following the 2008 financial crisis. Further, according to the Statistical Review Report 2019 of the WTO, the volume of world merchandise trade as measured by the average exports and imports, increased by $3 \%$ in 2018. Developing economies also exported a total of US\$ 8,779 billion in 2018 of which US\$ 193 billion dollars were from least-developed countries. In summary, world trade 
\& GDP grew by $26 \%$ since 2008 . World trade has been in a positive trend since the 1950 s and from 1980-2002, it has tripled (Ortiz-Ospina, Beltekian, \& Roser, 2018; Barriel \& Dean, 2005). Additionally, according to the Statistical Review Report 2020 of the WTO, in 2019 before the covid-19 pandemic situation the world trade declined in volume by $0.1 \%$ and merchandise trade fell by $3 \%$ due to political tensions and protectionist measures. So, the average trend of world trade before covid-19 is upward with exceptions in some cases.

\section{World trade during COVID-19 Pandemic}

Most of the countries chose a lockdown process to protect their citizens from virus infections. This system causes significant shocks in demand and supply which impact almost all the sectors, i.e. liquidity crisis and resources \& inventory breakdown of SME. According to WTO (2018), the three leading players of merchandise trade in 2017 are China, US and Germany. China alone covers $60 \%$ of demand and supply in the world. Hence, the decline of China's world trade fall impacts the rest of the world's trade. The world trade US government will be reduced by US\$ 905 billion and US\$ 2095 billion in short containment and long containment scenarios respectively (HASSANI \& DOST 2020). Moreover, a causal relationship exists between COVID-19 deaths and exports and imports of China. For the USA, both Covid-19 deaths and cases have a direct causal relationship with exports and imports (Zhang, Dawei, Majeed, \& Sohail, 2021). As it is mentioned above, since 2019, world trade has been facing challenges prior Covid-19 pandemic. This pandemic has caused an extra massive impact on world trade. Global trade decreased by $6 \%$ in 1Q20 year on year, followed by a decrease of $21 \%$ year on year in 2 Q20. The volume of trade also dropped by $3 \%$ in 1Q20 compared to 4Q19 and continued its drop by $14 \%$ in 2Q20 (IFC, 2020). The disruption of world trade has precipitously begun from the first half of 2020. Purchasing managers' indices (PMIs) disclose new export orders of manufacturers and services have fallen straightly 27.1 and 21.7 respectively in April 2021 compared with a baseline value of 50. In May 2020, it slightly increased but remained below trend (WTO, 2020).

Most of the economies show a downward merchandise exports. The year-on-year percentage change of merchandise exports of selected leading traders as of April 2020 is not positive for most of the countries. It is ranged from $-2 \%$ to $-61 \%$. Some Asian economies have not experienced declines in exports but their imports are still negative. For instance, China experienced 14\% down in imports and Thailand experienced 17\% down in imports (WTO, 2020).

There is no scope for services such as goods to produce, store or sell at later stages. Consequently, there is no opportunity to recover the lost revenues for cancelled flights, restaurants meals or hotel bookings. International travels, cultural and recreational activities account for more than $40 \%$ of world services exports. The year-on-year monthly percentage change of services exports of selected leading traders as of March 2020 is also not positive for most of the countries. These are reduced tremendously. For instance, Italy's services exports fall by $40 \%$.In a comparison of services exports of March 2020 with 2019, almost half of world services exports fall by $15 \%$. More specifically, the leading services traders-US and UK, exports were reduced by $14 \%$ and $22 \%$ respectively. Some countries showed growth due to their dominated IT services, i.e., the services exports of India, Ukraine and Ireland were up by 1\%,3\% and $8 \%$ respectively for the first quarter of 2020 (WTO, 2020).

The impact of Covid-19 on other sectors also causes an impact for world trade as a consequence. This pandemic is considered as a threat and disaster for educational systems, tourism, health, financial system and economy of all countries (GRUSZCZYNSKI, 2020). For instances, this pandemic has not only affected China's international trade but also severely affected 
its air transportation sectors and tourisms such as- China's economy is shrank by $6.8 \%$ in the first quarter of 2020 (Ruiz Estrada, Park, \& Lee, 2020, Kazunobu \& Hiroshi, 2020). The covid-19 pandemic has turned the world into a recession in economies all over the world. There is also a downward trend in container shipping. In May 2020, a seasonal index of container port throughput was down 8 percent year-on-year. On the other hand, global commercial flights (both passenger $\&$ air transport) were reduced by 74 percent between 5 January and 18 April 2020. Consequently this caused a slowdown in merchandise trade and commercial services trade (WTO, 2020).

Due to the world trade and other sector disruptions there is a negative impact of Covid-19 on GDP. It fell by $2 \%$ which is below the benchmark of the world. The GDP of industrial countries and developing countries is reduced by $1.8 \%$ and $2.5 \%$ respectively (Maliszewska, Mattoo, \& van der Mensbrugghe, 2020). Further, China's GDP declined by $9.8 \%$ in the first quarter of 2020 in a comparison with the previous quarter. The United States and Euro areas also recorded a decline in GDP by $1.2 \%$ and $3.8 \%$ respectively. These all the rates are equivalent to the annualized of $-45 \%$, $-4.8 \%$ and $-14.4 \%$ respectively for China, US and Euro areas (WTO, 2020).

\section{COVID-19 pandemic and Global Financial Crisis (GFC)}

The world is experiencing the most disrupted global pandemic after the great depression of the 1930s and global financial crisis of 2008 (Mirza, Rahat, Naqvi, \& Rizvi, 2020). The financial crisis of 2008-2009 was the worst financial disruption since covid-19 pandemic. Although the causes of the financial crisis 2008 and covid-19 pandemic are different, there are similarities in consequences. Financial markets, world GDP, world trade and the economies of nations are being collapsed by both of these. But the depth of collapse is different. For instance, inflows of external private finance are estimated to fall by USD 700 billion compared to 2019. This impact is up by $60 \%$ compared to the GFC of 2008 (OECD, 2020). The economic growth rate of developing countries is expecting more negative and the developed countries growth rate is expecting $-5.8 \%$ in 2020 while it was $-3.4 \%$ in 2009 (UNCTAD, 2020). Further, in 2008-09 the PMI showed new exports of manufacturing was above 30 and in the first quarter of 2020 it is 27.1 with a baseline value of 50 (WTO, 2020). The sharp fall of global trade in the first few months of this pandemic exceeded the situation of the 2008-09 global financial crisis (IFC, 2020).

\section{World trade after this pandemic shock}

The third wave of covid-19 pandemic, especially Delta variant of India is shaking the world perilously. The world is searching for solutions to survive, i.e. the vaccination process. The countries also try to turn up their economies. The present situation of world trade is better than previous times of Q4 2019 and 2020. One of the most leading players of world trade, i.e China's international trade's growth rate is $28.2 \%$ year-on-year to 14.76 trillion yuan ( $\$ 2.3$ trillion) in the first five months of 2021. Statistical data of the General Administration of China (GAC) shows that the country's exports and imports had a growth of $30.1 \%$ \& $25.9 \%$ year-on-year to 8.04 trillion yuan and 6.72 trillion yuan respectively between January to May 2021 (Global times, 2021). In the first half of 2020, world trade experienced a sharp decline whereas it recovered faster than expected in the second half of the same year. The world merchandise trade growth is increased by $15 \%$ in the first quarter of 2021 relative to average of 2020.It is forecasted to increase of overall $8 \%$ for 2021 (WTO, 2021). Regional trade trends of exports \& imports in Q1 2021 increased by $12 \% \& 7 \%$ for developed countries and by $18 \%$ \& $22 \%$ for developing countries in comparison with Q1 2020. The global trade is forecasted to increase by $16 \%$ for the second quarter of 2021 (UNCTAD, 2021).Figure 1 shows the trade trends of exports and imports of major trading 
economies of Q1 2021. China, India and South Africa are in a relatively better situation than other major economies during Q1 2021.

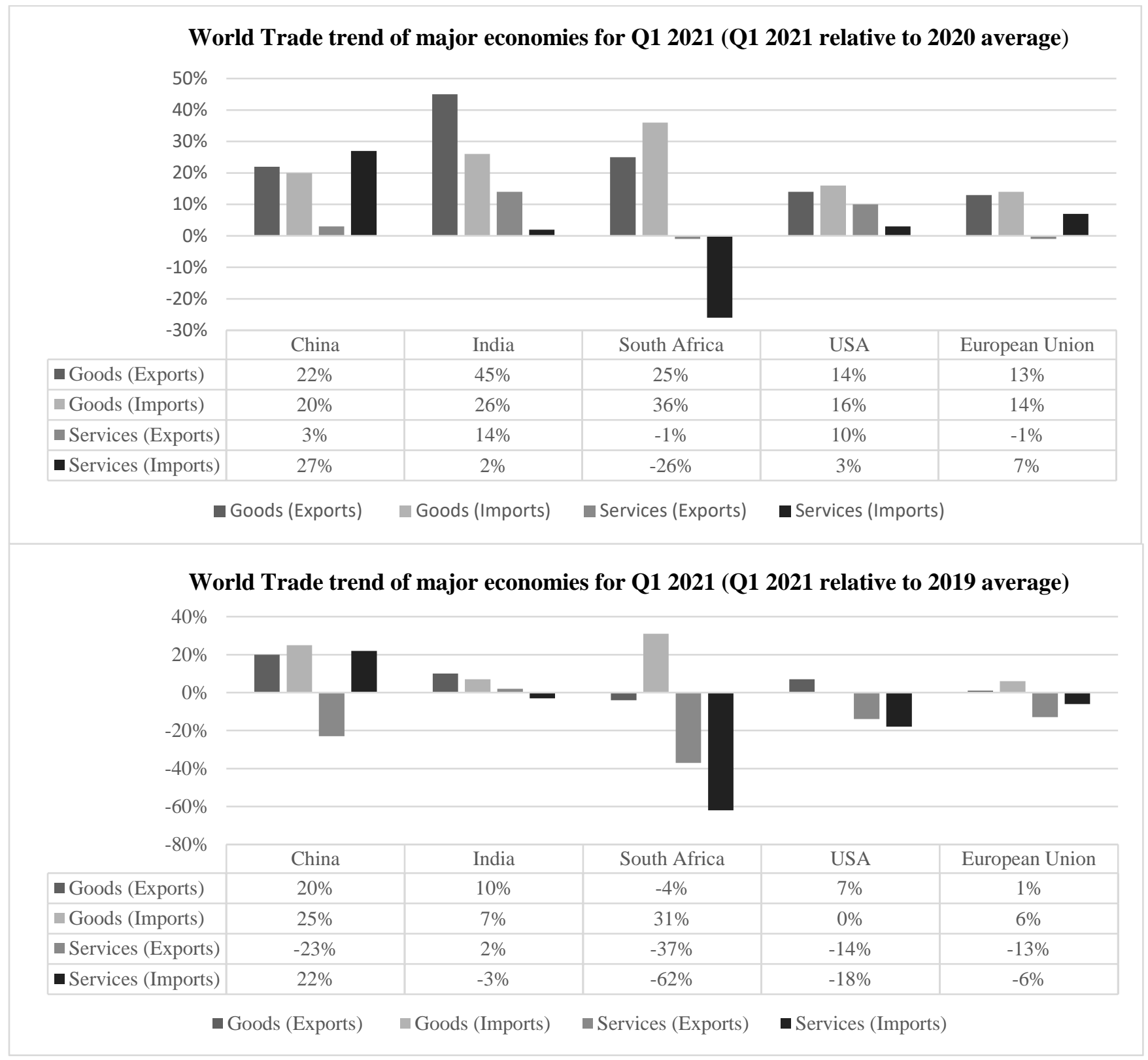

Figure 1. World Trade trend of major economies for Q1 2021

Source: UNCTAD

The recovery of goods is stronger than services. World services trade is falling $9 \%$ yearon-year in the first quarter of 2021. It was $21 \%$ down for all over the year of 2020. This services trade remained sluggish due to the weakness in travel services. Travel services are reduced by $62 \%$ in the first quarter of 2021. The new variants of covid-19 cause delayed recovery of international travel (WTO, 2021). The cumulative change in world trade from the start of each recession i.e., 2020, 2015, and 2009 shows a faster recovery of 2020. Recovery trend is faster than the previous trade recessions. (UNCTAD, 2021) 


\section{CONCLUSION}

Globalization of trade makes the world easier. At the same time it also acts as a channel for spreading crises. Due to this pandemic situation some countries may be gainful and some may be downfall in world trade. For instance, the countries which are specialized in making medical assistance goods or giving medical assistance services will be gainful in this pandemic. From the second half of 2020 the merchandise trade is in recovery whereas the services trade is in a sluggish position. The most relative reason for the slow recovery of services trade is the imposed restrictions on international travels and tourism. The interesting thing is that the developed countries lagged behind the developing countries in recovery of world merchandise trade. The better world trade averages of the East-Asian countries increases the total world trade averages of the developing countries. The trend of world trade recovery of COVID-19 pandemic is much better than the previous trade recessions. But this recovery trend is uneven. For example- China has a higher global trade growth than the other Asian countries. The uneven distribution of vaccines and the accurate solutions of cure for covid-19 is related to the slow economic recovery. The responsible organizations or authority should ensure an equal distribution of vaccines. The world has to discover the cure of this disease. These can lead the nations to normal life and consequently to a fast recovery of world trade as well as economy.

\section{REFERENCES}

Barriel, M., \& Dean, M. (2005). Why has world trade grown faster than world output? (SSRN Scholarly Paper ID 700072). Social Science Research Network. https://papers.ssrn.com/ abstract $=700072$

Baqir, M., Hussain, S., Waseem, R., \& Islam, K. (2020). Impact of Reward and Recognition, Supervisor Support on Employee Engagement. American International Journal of Business and Management Studies, 8-21.

China's foreign trade grows $28.2 \%$ in first five months - Global Times. (2021). Retrieved 27 July 2021, from https://www.globaltimes.cn/page/202106/1225557.shtml

Glick, R., \& Rose, A. (1999). Contagion and trade. Journal of International Money and Finance, 18(4), 603-617.

Global Trade Update (May 2021) | UNCTAD. (2021). Retrieved 27 July 2021, from https://unctad.org/webflyer/global-trade-update-may-2021

GRUSZCZYNSKI, L. (2020). The COVID-19 Pandemic and International Trade: Temporary Turbulence or Paradigm Shift? European Journal of Risk Regulation, 11(2), 337-342.

HASSANI, K., \& DOST, S. (2020). Impact of COVID 19 on international trade and China's trade. Turkish Economic Review, 7(2), 103-110.

Impact of the COVID-19 pandemic on trade and development: transitioning to a new normal | UNCTAD. (2020). Retrieved 26 July 2021, from https://unctad.org/webflyer/impactcovid-19-pandemic-trade-and-development-transitioning-new-normal 
Imran, M., \& Ahmed, I. (2020). Job Insecurity in Private Education Sector Considering COVID19 Pandemic: Bangladesh Panorama. American International Journal of Business and Management Studies, 41-51.

Kazunobu, H., \& Hiroshi, M. (2020). Impacts of covid-19 on international trade: evidence from the first quarter of 2020.IDE Discussion Paper,791. Retrieved from http://hdl.handle.net/2344/00051734

Khan, R. (2020). Impact of Monetary Policies on the Exchange Rate and Global Trade Evidence from Ghana. American International Journal of Business and Management Studies, 1-15.

Koka, B., Prescott, J., \& Madhavan, R. (1999). Contagion Influence on Trade and Investment Policy: A Network Perspective. Journal of International Business Studies, 30(1), 127147.

Maliszewska, M., Mattoo, A., \& van der Mensbrugghe, D. (2020). The Potential Impact of COVID-19 on GDP and Trade: A Preliminary Assessment. Policy Research Working Paper 9211, The World Bank, Retrieved 22 July 2021, from https://papers.ssrn.com/sol3/papers.cfm?abstract_id=3573211

Mirza, N., Rahat, B., Naqvi, B., \& Rizvi, S. (2020). Impact of Covid-19 on corporate solvency and possible policy responses in the EU. The Quarterly Review of Economics and Finance.

Ortiz-Ospina, E., Beltekian, D., \& Roser, M. (2018). Trade and globalization. Our World in Data. https://ourworldindata.org/trade-and-globalization

Relman, D., Choffnes, E., \& Mack, A. (2010). Infectious disease movement in a borderless world. Washington, D.C.: National Academies Press.

Ruffin, R. (2002). David Ricardo's Discovery of Comparative Advantage. History of Political Economy, 34(4), 727-748.

Ruiz Estrada, M., Park, D., \& Lee, M. (2020). The Evaluation of the Final Impact of Wuhan COVID-19 on Trade, Tourism, Transport, and Electricity Consumption of China. SSRN Electronic Journal.

Salik, S., \& Chowdhury, M. (2020). Impact of COVID on Online Teaching Platform: Study on IB Curriculum in Bangladesh. American International Journal of Business and Management Studies, 1-7.

Serrano, M., \& Boguñá, M. (2003). Topology of the world trade web. Physical Review E, 68(1).

Services trade slump persists as travel wanes; other service sectors post diverse gains. WTO. (2021). $\quad$ Retrieved $27 \quad$ July $2021, \quad$ from https://www.wto.org/english/news_e/news21_e/serv_23jul21_e.htm 
The impact of the coronavirus (COVID-19) crisis on development finance. (2020). Retrieved 23 July 2021, from https://www.oecd.org/coronavirus/policy-responses/the-impact-of-thecoronavirus-covid-19-crisis-on-development-finance-9de00b3b/

Trade forecast press conference- WTO. (2021). Retrieved 27 July 2021, from https://www.wto.org/english/news_e/spra_e/spra303_e.htm

When Trade Falls-Effects of COVID-19 and Outlook. Retrieved 15 July 2021, from https://www.ifc.org/wps/wcm/connect/publications_ext_content/ifc_external_publicatio n_site/publications_listing_page/trade-and-covid-19-note-1

World Health Statistics 2021: A visual summary. (2021). Retrieved 13 July 2021, from https://www.who.int/ data/stories/world-health-statistics-2021-a-visual-summary

WTO | Trade Statistics - World Trade Statistical Review 2018. Retrieved 14 July 2021, from https://www.wto.org/english/res_e/statis_e/wts2018_e/wts18_toc_e.htm

WTO | Trade Statistics - World Trade Statistical Review 2019. Retrieved 14 July 2021, from https://www.wto.org/english/res_e/statis_e/wts2019_e/wts19_toc_e.htm

WTO | Trade Statistics - World Trade Statistical Review 2020. Retrieved 14 July 2021, from https://www.wto.org/english/res_e/statis_e/wts2020_e/wts20_toc_e.htm

WTO Statistics: Latest trade trends. (2021). Retrieved 27 July 2021, from https://www.wto.org/english/res_e/statis_e/latest_trends_e.htm

Zhang, W., Dawei, W., Majeed, M., \& Sohail, S. (2021). COVID-19 and international trade: insights and policy challenges in China and USA. Economic Research-Ekonomska Istraživanja, 1-12.

\section{Copyrights}

Copyright for this article is retained by the author(s), with first publication rights granted to the journal. This is an open-access article distributed under the terms and conditions of the Creative Commons Attribution license (https://creativecommons.org/licenses/by/4.0). 